\title{
METODE KONTRASEPSI TUBEKTOMI MENURUT PENGETAHUAN PASANGAN USIA SUBUR
}

\author{
Linda Amalia ${ }^{{ }^{*}}$ \\ 1. Program Studi Keperawatan, FPOK UPI Bandung, Bandung-Indonesia \\ *Korespondensi: Linda Amalia | UPI Bandung | lindamalia16@upi.edu
}

\begin{abstract}
Abstrak
Pendahuluan: Tubektomi merupakan salah satu metode kontrasepsi yang paling efektif untuk mencegah kehamilan karena bersifat permanen dan memiliki tingkat efektifitas yang tinggi. Tujuan dari penelitian ini adalah untuk mengetahui gambaran pengetahuan Pasangan Usia Subur (PUS) tentang metode kontrasepsi Tubektomi.

Metode: Metode penelitian ini menggunakan deskriptif survei. Jumlah sampel 91 responden dengan tekhnik Proposional Stratified Random Sampling. Data diperoleh dengan cara membagikan kuesioner secara langsung kepada pasangan usia subur di Desa Nagrak Kabupaten Cianjur.

Hasil: Hasil analisa data didapatkan tingkat pengetahuan PUS tentang Tubektomi dengan kategori baik sebanyak 7 responden (8\%), cukup sebanyak 46 responden (51\%), dan pengetahuan kurang sebanyak 38 responden $(41 \%)$.

Kesimpulan: Dari hasil penelitian di atas dapat disimpulkan bahwa gambaran pengetahuan pasangan usia subur tentang MOW/Tubektomi termasuk pada kategori cukup. Oleh karena itu diharapkan kepada para instansi terkait untuk lebih meningkatkan kinerja dalam upaya meningkatkan pengetahuan dan motivasi pasangan usia subur (PUS) dan masyarakat tentang Tubektomi.
\end{abstract}

Kata Kunci: Pengetahuan, Kontrasepsi,Tubektomi.

Diterima 29 November 2019; Accepted 30 Desember 2019

\section{PENDAHULUAN}

Jumlah penduduk dunia semakin hari semakin bertambah. Jumlah penduduk dari tiap-tiap negara berbeda-beda. Bisa difaktorkan oleh luas negara, kesuburan penduduk, kemampuan finansial, dan lain-lain. Dengan jumlah penduduk yang amat banyak dan terusbertambah setiap harinya, tentu ini akan menimbulkan suatu masalah. Dunia yang kita tempati ini memiliki195 negara dengan jumlah penduduk atau populasi saat ini mecnapai 7,2 miliar jiwa. Angka kelahiran bayi diseluruh dunia sekitar 300 ribu perhari, orang yang meninggal rata-rata 156.000 orang perhari dan pertumbuhan manusia sekitar 145.000 orang perhari. (Robin, 2013)

Republik Rakyat Cina menempati urutan pertama dan merupakan negara yang memiliki populasi atau jumlah penduduk terbanyak di dunia dengan jumlah penduduknya sekitar 1,3 miliarjiwa atau tepatnya 1.349.585.383 jiwa. Angka tersebut merupakan 19\% dari keseluruhan jumlah penduduk dunia. Sedangkan negara Republik Indonesia menduduki urutan keempat dengan jumlah penduduknya 252.370.792 jiwa atau sekitar $4 \%$ dari keseluruhan jumlah penduduk dunia.

Kebanyakan negara dengan penyumbang jumlah penduduk terbesar umumnya berada di benua-benua Asia, dan umumnya pada negara-negaraberkembang yang jumlah perkembangan penduduknya lebih tinggi dibandingkan dengan negara-negara maju. Negara berkembang mempunyai jumlah pertumbuhan penduduk diatas $1 \%$ pertahun, sementara negera maju masih tinggi. Singapura satu-satunya negara maju di ASEAN memiliki perkiraan laju pertumbuhan penduduk paling rendah yaitu 0,6\% (Profil Kesehatan Indonesia, 2013).

Dalam melaksanakan pembangunan nasional, Indonesia masih dihadapkan pada masalah jumlah penduduk yang besar karena jumlah persentase natalitas di Indonesia yang tinggi. Indonesia menduduki peringkat 8 perkiraan laju pertumbuhan penduduk di ASEAN dengan prosentase 1,1\%. Saat ini angka kelahiran di Indonesia masih mencapai 2,6 juta pertahun (Syarief 2010). Berbagai upaya dilakukan untuk menekan angka kelahiran diantaranya melalui program Keluarga Berencana (KB). (Anonim, 2011)

Saat ini, angka pertumbuhan penduduk di Indonesia menurut data hasil Sensus Penduduk tahun 2010 yang diadakan setiap 10 tahun sekali mencapai 237.641.326 juta jiwa. Jika dibandingkan dengan hasil sensus penduduk tahun 2000, yakni mencapai 205.132.458 juta jiwa, Indonesia mengalami pertambahan penduduknya sekitar 32.508 .868 per 10 tahunnya. Ini menunjukkan bahwa program Keluarga Berencana (KB) dari tahun ke tahun kurang berjalan dengan efektif (BKKBN RI 2010). Jika kita menggunakan data 
pertumbuhan penduduk Indonesia yang dikeluarkan oleh Departemen Dalam Negeri yakni $1.21 \%$ pertahun, maka jumlah penduduk Indonesia tahun 2015 ini akan menjadi 252.370,792 jiwa.

Provinsi paling tinggi angka kepadatan penduduknya yakni di Jawa Barat, mencapai 43.053 .732 juta jiwa. Di Jawa Barat sendiri, 6 besar daerah atau Kabupaten tertinggi angka kepadatannya yakni Kabupaten Bogor (4.771.932 juta jiwa), Bandung (3.178.543 juta jiwa), Bekasi (2.630.791 juta jiwa), Garut (2.404.121 juta jiwa), Sukabumi (2.341.409 juta jiwa), dan Cianjur (2.171.281 juta jiwa) (Sensus Penduduk 2010).

Di Indonesia, Pasangan Usia Subur (PUS) yang menggunakan metode kontrasepsi terus meningkat mencapai $61.4 \%$. Pola pemakaian kontrasepsi terbesar yaitu suntik sebesar31,6\%, pil sebesar 13,2\%, IUD sebesar 4,8\%, implant sebesar 2,8\%, kondom sebesar $1,3 \%$ kontap wanita sebesar 3,1\%, kontap pria sebesar $0,2 \%$, pantang berkala $1,5 \%$, senggama terputus $2,2 \%$, dan metode lainnya $0,4 \%$ (Depkes RI 2010). Jumlah akseptor KB di Jawa Barat sebanyak 1.423 .800 orang. Pengguna suntik 55,36\%, pil 29,85\%, IUD $8,04 \%$, MOW 2,65\%, implant 2,50\%, kondom 1,31\%, Metode Operasi Pria (MOP) 0,29\%. (BKKBN RI 2010).

Keluarga Berencana $(\mathrm{KB})$ adalah tindakan yang membantu pasangan suami istri untuk menghindarkan kehamilan yang tidak diinginkan, mendapatkan kelahiran yang memang diinginkan, mengatur interval kehamilan, mengontrol waktu saat kelahiran dalam hubungan dengan umur suami istri serta menentukan dalam jumlah anak dan keluarga (Suratun, 2008). KB mempunyai peranan dalam menurunkan resiko kematian ibu melalui pencegahan kehamilan atau membatasi kehamilan bila anak dianggap cukup. Setiap wanita berhak memperoleh informasi dan mempunyai akses terhadap metode KB yang mereka pilih efektif, aman, terjangkau dan juga metode-metode pengendalian kehamilan yang tidak bertentangan dengan hukum dan perundang-undangan yang berlaku (Pinem, 2009).

Permasalahan kesehatan reproduksi masih banyak sekali yang harus dikaji, tidak hanya organ reproduksi saja tetapi ada beberapa aspek, salah satunya adalah kontrasepsi. Kontrasepsi adalah menghindari atau mencegah terjadinya kehamilan sebagai akibat pertemuan antara sel telur yang matang dengan sel sperma. Meskipun masing-masing jenis kontrasepsi memiliki tingkat efektivitas yang tinggi dan hampir sama, akan tetapi efektivitas kontrasepsi juga dipengaruhi oleh perilaku dan tingkat sosial budaya pemakainya (Khaidirmuhaj, 2015)

Pengguna kontrasepsi di Desa Nagrak bulan April 2015 terdapat 2263 akseptor aktif. Akseptor KB suntik sebanyak 1179 orang $(52,10 \%)$, akseptor pil sebanyak 551 orang $(24,35 \%)$, akseptor IUD sebanyak 279 orang $(12,33 \%)$, akseptor implant sebanyak 94 orang $(4,15 \%)$, akseptor Metode Operasi Wanita (MOW)/Tubektomi sebanyak 90 orang $(3,98 \%)$, akseptor kondom sebanyak 46 orang $(2,03 \%)$ dan akseptor MOP sebanyak 24 orang (1,06\%). (Arsip Desa Nagrak, 2015).

Berdasarkan studi pendahuluan awal yang peneliti lakukan dengan cara wawancara dengan 20 responden di Desa Nagrak Kabupaten Cianjur, diperoleh data 6 orang responden mengatakan mengetahui tentang metode KB Tubektomi, sedangkan 14 orang menyatakan bahwa mereka tidak mengetahui tentang alat kontrasepsi tersebut dan mereka tidak memakai alat kontrasepsi MOW/Tubektomi, sehingga menyulitkan mereka dalam mendapatkan akses pemilihan layanan kesehatan kontrasepsi khususnya pelayanan kontrasepsi KB MOW/Tubektomi ini.

Atas dasar pemikiran diatas, peneliti dirasa penting untuk melakukan pelenitian mengenai Gambaran Pengetahuan Pasangan Usia Subur tentang MOW/Tubektomi di Desa Nagrak Kabupaten Cianjur.

\section{METODE}

Dalam penelitian ini peneliti menggunakan metode penelitian deskriptif. Populasi yang akan diteliti adalah seluruh pasangan usia subur yang tinggal di Desa Nagrak Kabupaten Cianjur, sebanyak 915 orang. Dari jumlah populasi tersebut dengan tingkat kelonggaran ketidakefektifan sebesar 10\%, maka dengan menggunakan rumus $n=\frac{\mathrm{N}}{1+N(d)^{2}}$ di peroleh sampel sebesar 91 orang. Karena Desa Nagrak Kecamatan Cianjur Kabupaten Cianjur terbagi 17 RW, maka peneliti membagi secara rata sampel yang akan diteliti sehingga setiap RW mempunyai kuota sampel yang sama besar dan merata yaitu 6,6-7 responden.

Metode pengambilan sampel yang digunakan adalah teknik Proporsional Stratified Random Sampling yaitu pengambilan sampel acak secara proporsional.

Data yang terkumpul dalam penelitian ini adalah data primer yaitu data yang diperoleh secara langsung dan diberikan pengarahan tentang penelitian yang dilakukan dengan kuesioner yang akan dibagikan, kemudian lembaran kuesioner dibagi kepada kepala keluarga untuk diisi dan dijawab sesuai dengan 
pertanyaan yang terdapat pada lembaran kuesioner yang berisi tentang gambaran pengetahuan pasangan usia subur tentang Tubektomi di Desa Nagrak Kabupaten Kabupaten Cianjur.

Intrumen yang digunakan dalam penelitian ini adalah kuesioner. Kuesioner ini terdiri dari: kuesioner data demografi klien yang meliputi umur/usia, pendidikan, pekerjaan, jarak terhadap pelayanan kesehatan dan kuesioner tentang gambaran pengetahuan pasangan usia subur tentang Tubektomi di Desa Nagrak Kabupaten Cianjur.

Uji Validitas dan Realibilitas ini telah dilakukan di Desa Sukamaju Kecamatan Cianjur Kabupaten Cianjur terhadap 30 responden dengan 30 soal, hasil uji validitas didapatkan angka $r_{\text {tabelnya }} 0,463$, yaitu 25 pertanyaan valid dan 5 soal tidak valid. Hasil uji realibilitas didapatkan nilai Alpha 0,955 lebih besar dibandingkan $r_{\text {tabelnya }} 0,463$ maka pertanyaan tersebut dinyatakan sudah reliable.

Data penelitian yang telah didapatkan, data dianalisa secara univariat. Penelitian ini telah dilakukan di Desa Nagrak Kecamatan Cianjur Kabupaten Cianjur, sedangkan penelitian ini dilakukan pada bulan Februari-Juli 2015.

\section{HASIL}

Penelitian mengenai gambaran pengetahuan pasangan usia subur tentang Tubektomi di Desa Nagrak Kecamatan Cianjur Kabupaten Cianjur yang dilaksanakan pada 91 responden. Penelitian ini bertujuan untuk mengetahui "Gambaran Pengetahuan Pasangan Usia Subur (PUS) tentang Tubektomi di Desa Nagrak Kecamatan Cianjur kabupaten Cianjur Tahun 2015".

Tabel 1. Data demografik dan tempat pelayanan kesehatan

\begin{tabular}{lc}
\hline \multicolumn{1}{c}{ Karakteristik } & $\mathbf{N}(\%)$ \\
\hline Pendidikan & $2(2,2)$ \\
Tidak pernah sekolah & $21(23,1)$ \\
Sekolah Dasar & $36(39,6)$ \\
Sekolah Lanjutan Tingkat Pertama & $28(30,8)$ \\
Sekolah Lanjutan Tingkat Atas & $4(4,4)$ \\
PT/Akademi & \\
& \\
Pekerjaan & $74(81,3)$ \\
Tidak bekerja & $4(4,4)$ \\
Pegawai Negri Sipil & $13(14,3)$ \\
Wiraswasta & \\
& \\
Tempat pelayanan kesehatan & $64(70,3)$ \\
Puskesmas & $23(25,3)$ \\
Bidan praktek & $3(3,3)$ \\
Rumah sakit & $1(1,1)$ \\
Dokter spesialis & \\
& \\
Jarak ke tempat pelayanan kesehatan & $13(14,3)$ \\
500 m & $45(49,5)$ \\
1 - 5 km -1 km & $22(24,2)$ \\
$\geq 5$ km & $11(12,1)$ \\
\hline
\end{tabular}

Table 1 menggambarkan data karakteristik respoden dari 91 responden menunjukkan seperti terlihat dalam table 1. bahwa karakteristik pasangan usia subur berdasarkan umur/usia, menunjukkan bahwa sebagian kecil responden berumur 25-35 tahun dengan jumlah 43 orang (43.3\%), hampir setengah dari responden berumur 36-40 tahun dengan jumlah 34 orang $(37.4 \%)$ dan hampir setengah dari responden berumur $\geq 41$ tahun dengan jumlah 43 orang $(47,3 \%)$.

Data karakteristik responden berdasarkan pendidikan menunjukkan bahwa pasangan usia subur sebagian kecil dari responden tingkat pendidikan SD dengan jumlah 21 orang $(23,1 \%)$, hampir setengah dari responden tingkat pendidikan SLTP dengan jumlah 36 orang $(39,6 \%)$, hampir setengah dari responden tingkat pendidikan SLTA dengan jumlah 28 orang (30,8\%), sebagian kecil dari responden tingkat 
pendidikan PT/Akademi dengan jumlah 4 orang $(4,4 \%)$ dan sebagian kecil dari responden tidak pernah sekolah dengan jumlah 2 orang $(2,2 \%)$.

Karakteristik responden berdasarkan pekerjaan, menunjukkan bahwa hampir seluruh dari responden tidak bekerja dengan jumlah 74 orang $(81,3 \%)$ sebagian kecil dari responden bekerja sebagai PNS dengan jumlah 4 orang $(4,4 \%)$ dan sebagian kecil responden bekerja sebagai wiraswasta dengan jumlah 13 orang $(14,3 \%)$.

Karakteristik responden berdasarkan Tempa Pelayanan KB menunjukkan bahwa sebagian besar dari responden mendapatkan pelayanan KB di Puskesmas dengn jumlah 64 orang (70,3\%), sebagin kecil dari responden mendapat pelayanan KB di Bidan dengan jumlah 23 orang $(25,3 \%)$, sebagian kecil dari responden mendapatkan pelayanan KB di Rumah Sakit dengan jumlah 3 orang $(3,3 \%)$ dan sebagian kecil dari responden mendapat pelayanan KB dari Dokter Spesialis dengan jumlah 1 orang $(1,1 \%)$.

Karakteristik responden berdasarkan jarak dengan tempat pelayanan KB menunjukkan bahwa sebagian kecil dari responden yang berjarak 500 meter dengan tempat pelayanan KB berjumlah 13 orang (14,3\%), hampir setengah dari responden yang berjarak $500 \mathrm{~m}-1 \mathrm{Km}$ dengan tempat pelayanan KB berjumlah 45 orang $(49,5 \%)$, sebagian kecil dari responden yang berjarak $1-5 \mathrm{Km}$ dengan tempat pelayanan $\mathrm{KB}$ berjumlah 22 orang $(24,2 \%)$ dan sebagian kecil dari responden yang berjarak $\geq 5 \mathrm{Km}$ dari tempat pelayanan KB berjumlah 11 orang $(12,1 \%)$.

Tabel 2. Distribusi pengetahuan pasangan usia subur tentang MOW/Tubektomi

\begin{tabular}{lccc}
\hline \multicolumn{1}{c}{ Uraian } & Baik (\%) & Cukup (\%) & Kurang (\%) \\
\hline Pengetahuan secara umum & $7(8)$ & $46(51)$ & $38(41)$ \\
Pengertian & $28(30,8)$ & $38(41,8)$ & $25(27,5)$ \\
Kelebihan dan kekurangan & $12(13,2)$ & $36(39,6)$ & $53(47,3)$ \\
Efek samping & $14(15,4)$ & $49(53,8)$ & $28(30,8)$ \\
Perawatan post operasi & $10(11)$ & $30(33)$ & $51(56)$ \\
Persyaratan & $15(16,5)$ & $15(16,5)$ & $44(48,4)$ \\
\hline
\end{tabular}

Table 2 menggambarkan data pengetahuan pasangan usia subur tentang Tubektomi secara umum diketahui bahwa sebagian kecil dari responden yaitu 7 orang (8\%) mempunyai pengetahuan yang baik, sedangkan sebagian besar dari responden yaitu 46 orang (51\%) memiliki pengetahuan yang cukup, dan hampir setengah dari responden yaitu 38 orang (41\%) memiliki pengetahuan yang kurang.

Pengetahuan pasangan usia subur tentang pengertian Tubektomi dari 91 responden memperlihatkan bahwa hampir setangah dari responden yaitu 28 orang $(30,8 \%)$ mempunyai pengetahuan yang baik, dan hampir setengah dari responden yaitu 38 orang $(41,8 \%)$ memiliki pengetahuan yang cukup, serta hampir setengah dari responden yaitu 25 orang $(27,5 \%)$ memiliki pengetahuan yang kurang.

Pengetahuan pasangan usia subur tentang kelebihan dan kekurangan Tubektomi dari 91 responden memperlihatkan bahwa sebagian kecil dari responden yaitu 12 orang $(13,2 \%)$ mempunyai pengetahuan yang baik, dan hampir setangah dari responden yaitu 36 orang $(39,6 \%)$ memiliki pengetahuan yang cukup, serta hampir dari setengah responden yaitu 53 orang $(47,3 \%)$ memiliki pengetahuan yang kurang.

Pengetahuan pasangan usia subur tentang Efek Samping Tubektomi dari 91 responden memperlihatkan bahwa sebgian kecil dari responden yaitu 14 orang $(15,4 \%)$ mempunyai pengetahuan yang baik, sedangkan sebgaian besar dari responden yaitu 49 orang $(53,8 \%)$ memiliki pengetahuan yang cukup, dan hampir dari setengah responden yaitu 28 orang $(30,8 \%)$ responden memiliki pengetahuan yang kurang.

Pengetahuan pasangan usia subur tentang Perawatan Setelah Tindakan Operasi Tubektomi dari 91 responden memperlihatkan bahwa sebagian kecil dari responden yaitu 10 orang (11\%) mempunyai pengetahuan yang baik, sedangkan hampir setengah dari responden yaitu 30 orang (33\%) memiliki pengetahuan yang cukup, dan sebagian besar dari responden yaitu 51 orang (56\%) responden memiliki pengetahuan yang kurang.

Pengetahuan pasangan usia subur tentang Persyaratan Untuk Melakukan Tubektomi dari 91 responden memperlihatkan bahwa sebagian kecil dari responden yaitu 15 orang $(16,5 \%)$ mempunyai pengetahuan baik, sedangkan hampir setengah dari responden yaitu 32 orang $(35,2 \%)$ mempunyai pengetahuan yang cukup, dan hampir setengah dari responden yaitu 44 orang $(48,4 \%)$ memiliki pengetahuan yang kurang.

\section{PEMBAHASAN}


Berdasarkan hasil penelitian yang telah dilakukan kepada 91 pasangan usia subur di Desa Nagrak Kecamatan Cianjur Kabupaten Cianjur tentang Tubektomi didapatkan bahwa sebagian besar responden 46 orang (51\%) memiliki pengetahuan cukup.

Hal ini sesuai dengan teori menurut Ryanto (2014) pengetahuan merupakan aspek yang paling penting dalam kehidupan sehingga orang bisa mengetahui mana yang baik mana yang salah. Hasil penelitian ini diperkuat oleh penelitian Isiyatin (2012), dalam penelitian yang dilakukan pada 88 akseptor KB di wilayah Cimahi selatan tentang KB MOW diperoleh data bahwa mayoritas pengetahuan akseptor KB cukup, yaitu sejumlah 44 responden $(74,5 \%)$.

Sedikitnya jumlah responden yang memiliki pengetahuan baik dapat disebabkan karena sebagian besar responden tempat pelayanan $\mathrm{KB}$ adalah di Puskesmas sedangkan untuk tindakan tubektomi harus dilakukan di rumah sakit karena melalui tindkan pembedahan, sehingga tenaga kesehatan di puskesmas akan sedkit sekali memberikan informasi tentang tubektomi. Peran serta kader dan instansi terkait juga sangat penting dalam penyampaian promosi kesehatan dalam strateginya untuk menciptakan masyarakat yang sadar akan pentingnya keluarga berencana sebagai unit terpenting dalam memperoleh kesejahteraan.

Berdasarkan hasil penelitian pada 91 responden untuk mengetahui tentang pengetahuan pasangan usia subur tentang pengertian Tubektomi di Desa nagrak Kecamatan Cianjur Kabupaten Cianjur, hampir setengah dari responden yaitu 38 orang $(41,8 \%)$ memiliki pengetahuan yang cukup tentang pengertian Tubektomi. Hal ini diperkuat oleh Saebani (2008), pengetahuan adalah segala sesuatu yang telah dikerahui. Adapun cara mengetahui sesuatu dapat dilakukan dengan cara mendengar, melihat, merasa, dan sebagainya, yang merupakan bagian dari alat indra manusia. Menurut Ryanto (2014) informasi mempengaruhi pengetahuan seseorang, informasi yang diperoleh dari pendidikan formal maupun nonformal dapat memberikan pengaruh jangka pendek (immediate impact) sehingga menghasilkan perubahan atau peningkatan pengetahuan. Berkembangnya teknologi akan menyediakan bermacam-macam media masa yang dapat mempengaruhi pengetahuan masyarakat tentang inovasi baru.

Berdasarkan hasil penelitian tentang pengetahuan pasangan usia subur tentang pengertian Tubektomi dalam kategori cukup. Kondisi ini dapat terjadi karena sebagian besar responden memiliki dasar pendidikan yang rendah sehingga untuk memahami tentang suatu definisi /pengertian akan lebih sulit. selain itu status pekerjaan responden yang sebagian besar tidak bekerja akan menyebabkan kurang nya informasi yang diperoleh karena lebih banyak berdiam di rumah. sedikitnya inInformasi adalah suatu komponen yang penting dalam menentukan seberapa tinggi tingkat pengetahuan pasangan usia subur tentang pengertian Tubektomi, dalam konteks ini adalah menciptakan perilaku keluarga yang sadar akan pentingnya keluarga yang terencana dan sejahtera, melalui informasi tentang KB.

Berdasarkan hasil penelitian tentang gambaran pengetahuan pasangan usia subur tentang kelebihan dan kekurangan Tubektomi ternyara hampir dari setengah respondennya yaitu 43 orang $(47,3 \%)$ memiliki pengetahuan yang kurang tentang kelebihan dan kekurangan Tubektomi.

Pendidikan adalah proses perubahan sikap dan perilaku seseorang atau kelompok dan merupakan usaha mendewasakan manusia melalui upaya pengajaran dan pelatihan. (Budiman \& Riyanto, 20130). Melalui pendidikan dapat meningkatkan keterampilan profesional dan pengetahuan spesifik yang masih relevan dengan pengetahuan umum. Akhirnya pendidikan dapat membentuk disposisi, perilaku dan kepribadian. Di sekolah orang disosialisasikan untuk menjadi lebih mandiri, lebih memotivasi diri, percaya diri, dan dapat menciptakan modal sosial. (Pradono dan Sulitiyowati, 2013).

Berdasarkan hasil penelitian dan ditunjang dari teori bahwa pengetahuan pasangan usia subur tentang kelebihan dan kekurangan Tubektomi dalam kategori kurang. Menurut peneliti pengetahuan kurang tersebut dopengaruhi oleh pendidikan, karena semakin tinggi pendidikan seseorang semakin mudah orang tersebut untuk menerima informasi. Dengan pendidikan tinggi, maka seseorang akan cenderung untuk mendapatkan informasi, baik dari orang lain maupun dari media masa. Semakin banyak informasi yang masuk semakin banyak pula pengetahuan yang didapat.

Berdasarkan hasil penelitian tentang mengetahui tentang gambaran pengetahuan pasangan usia subur tentang efek samping Tubektomi di Desa nagrak Kecamatan Cianjur Kabupaten Cianjur, ternyata sebagian besar dari respondennya yaitu 49 orang $(53,8 \%)$ memiliki pengetahuan yang cukup. Menurut Ryanto (2014), pengalaman belajar dalam bekerja yang dikembangkan memberikan pengetahuan dan keterampilan profesional serta pengalaman belajar selama bekerja akan dapat mengembangkan kemampuan mengambil keputusan yang merupakan manifestasi dari keterpaduan menalar secara ilmiah dan etik yang bertolak dari 
masalah nyata dalam bidang kerjanya.

Berdasarkan hasil penelitian dan ditunjang dari teori bahawa pengetahuan pasangan usia subur tentang efek samping Tubektomi dalam kategori cukup. Menurut peneliti pengetahuan cukup tersebut dipengaruhi juga oleh pekerjaan, karena hampir dari seluruh responden tidak bekerja (IRT) sehingga pengalaman belajar dan pengetahuan yang didapat kurang.

Berdasarkan hasil penelitian yang dilakukan kepada 91 responden untuk mengetahui tentang gambaran pengetahuan pasangan usia subur tentang perawatan setelah melakukan operasi Tubektomi di Desa nagrak Kecamatan Cianjur Kabupaten Cianjur, ternyata sebagian besar dari respondennya yaitu 51 orang (56\%) memiliki pengetahuan yang kurang tentang perawatan setelah melakukan operasi Tubektomi.

Tradisi atau budaya seseorang yang dilakukan tanpa penalaran apakah yang dilakukan baik atau buruk akan menambah pengetahuannta walaupun tidak melakukan. Seseorang yang mempunyai sosial budaya yang baik maka pengetahuannya akan baik, tetapi jika sosial budayanya kurang baik maka pengetahuannya akan kurang baik (Budiman dan Ryanto, 2013).

Berdasarkan hasil penelitian dan ditunjang dari teori bahwa pengetahuan pasangan usia subur tentang perawatan setelah operasi Tubektomi dalam kategori kurang. Menurut peneliti pengetahuan kurang tersebut dipengaruhi oleh faktor sosial dan budaya dimana masih banyak masyarakat Desa beranggapan bahwa Tubektomi adalah suatu tindakan yang tabu dan jarang dilakukan, karena masih banyak masyarakat yang menganggap tubektomi itu akan menyababkan seorang wanita menjadi mandul. Sehingga jika dibandingkan dengan metode kontrasepsi yang lain jumlah pengguna tubektomi hanya sedikit. Sedangkan semakin banyak orang melakukan Tubektomi sebagai alat kontrasepsi, maka akan semakin tinggi pula pengetahuan yang didapatkan oleh masyarakat (pasangan usia subur) begitupun sebaliknya.

Berdasarkan hasil penelitian yang dilakukan kepada 91 responden untuk mengetahui tentang gambaran pengetahuan pasangan usia subur tentang persyaratan untuk melakukan Tubektomi di Desa nagrak Kecamatan Cianjur Kabupaten Cianjur, ternyata hampir setengah dari respondennya yaitu 44 orang $(48,4 \%)$ memiliki pengetahuan yang kurang tentang syarat untuk melakukan Tubektomi.

Usia mempengaruhi daya tangkap pola pikir. Berdasarkan hasil penelitian dan ditunjang dari teori bahwa pengetahuan pasangan usia subur tentang syarat untuk melakukan Tubektomi dalam kategori kurang. Menurut peneliti pengetahuan kurang tersebut dipengaruhi oleh umur, karena hampir setengah dari responden berumur $\geq 41$ tahun sehingga akan sulit menerima pengetahuan yang baru karena daya tangkap dan pola pikirnya berkurang.

\section{KESIMPULAN}

Hasil penelitian yang telah dilakukan terhadap 91 responden didapatkan bahwa pengetahuan pasangan usia subur secara umum tentang Tubektomi sebagian besar dari responden yaitu 46 orang (51\%) memiliki pengetahuan yang cukup. Sedangkan pengetahuan pasangan usia subur secara subvariabel didapatkan hasil : 38 orang $(41,8 \%)$ memiliki pengetahuan yang cukup tentang Tubektomi, 43 orang $(47,3 \%)$ memiliki pengetahuan yang kurang tentang kelebihan dan kekurangan Tubektomi, 49 orang $(53,8 \%)$ memiliki pengetahuan yang cukup tentang efek samping Tubektomi, 51 orang $(56 \%)$ memiliki pengetahuan yang kurang tentang perawatan setelah tindakan operasi Tubektomi dan 44 orang $(48,4 \%)$ memiliki pengetahuan yang kurang tentang syarat untuk melakukan Tubektomi.

Faktor demografi berpengaruh pada tingkat pengetahuan PUS tentang metode MOW/Tubektomi. Tingkat pendidikan yang rendah dan tidak adanya pekerjaan menyebabkan PUS tidak mendapatkan informasi yang cukup tentang kesehatan, didukung juga dengan tempat yang pelayanan yang tidak menyediakan pelayanan kesehatan yang diperlukan, serta jarak yang cukup jauh menyebabkan informasi pelayanan MOW/Tubektomi menjadi tidak tersampaikan pada masyarakat sasaran yaitu Pasangan Usia Subur.

Bagi Puskesmas untuk meningkatkan kegiatan penyuluhan dan edukasi pada pasangan usia subur, serta tersedianya fasilitas sarana ataupun bantuan dana yang untuk merujuk dan melayani pasien ke Institusi pelayanan kesehatan yang melayani pemasangan MOW/Tubektomi.

\section{REFERENSI}

Anonim. (2011). MOW/Tubektomi. http://episitory.ipb.acc.id. diperoleh tanggal 24 Februari 2015. Arikunto, S. (2006). Prosedur Penelitian Suatu Pendekatan Praktik. Jakarta: Rineka Cipta. 
Arikunto, S. (2010). Prosedur penelitian suatu pendekatan praktik. Edisi Revisi 2010. Jakarta : Rineka Cipta.

Badan Pusat Statistik Kabupaten Cianjur. (2015). Kabupaten Cianjur Dalam Angka 2010. Cianjur : BPJS Kabupaten Cianjur.

Baradero, Mary, dkk. (2006). Klien Gangguan Sistem Reproduksi dan Seksualitas. Jakarta : EGC.

Budiman, Ryanro. (2013). Kapita Selekta Kuesioner Pengetahuan Dan Sikap Dalam Penelitian Kesehatan. Jakarta : Salemba Medika.

Cahyonoputro. (2009). Pengetahuan Faktor-Faktor yang Mempengaruhi,1, http://forbetterhealth.wordpress.com, diperoleh tanggal 20 Maret 2015.

Hartanto, H. (2004). Keluarga Berencana Dan Kontrasepsi. Jakarta : Pustaka Sinar Harapan

Hidayat, A. Aziz Alimul. (2007). Riset Keperawatan Dan Teknik Penulisan Ilmiah Edisi 2. Jakarta : Salemba Medika.

Khaidirmuhaj. (2015). http://khaidirmuhaj. blogspot.com, didapat tanggal 20 Maret 2015.

Manuaba, Ida Ayu, dkk. (2009). Memahami Kesehatan Reproduksi Wanita, Edisi 2. Jakarta: EGC.

Notoatmodjo, S. (2010). Metodologi Penelitian Kesehatan. Jakarta : PT Rineka Cipta.

Nursalam. (2008). Konsep Dan Penerapan Metodologi Penelitian Ilmu Keperawatan. Jakarta : penerbit salemba medika.

Pradono, Julianty, Sulistyowati. (2014). Hubungan antara tingkat pendidikan, pengetahuan, tentang kesehatan lingkungan, perilaku hidup sehat dengan status kesehatan; studi korelasi pada penduduk umur 10-24 tahun. Jakarta pusat : buletin penelitian sistem kesehatan, vol 17, no 1,89-95

Proverawati, Atika dkk. (2010). Panduan Memilih Kontrasepsi. Yogjakarta : Medical Book.

Robin. (2013). http://id.im.wikipedia.org/wiki/penduduk, diperoleh tanggal 1 April 2015.

Ryanto. (2014). Kapita Selekta Kuesioner Pengetahuan Dan Sikap Dalam Penelitian Kesehatan. Jakarta : salemba medika.

Setiadi. (2007). Konsep Dan Penulisan Riset Keperawatan. Yogjakarta : Graha Ilmu.

Suratun, dkk. (2008). Pelayanan Keluarga Berencana Dan Pelayanan Kontrasepsi. Jakarta : Trans Info Media.

Sugiyono. (2006). Statistika Untun Penelitian. Bandung : CV Alfabeta.

Syaifudin. (2010). Buku Panduan Praktis Pelayanan Kesehatan Maternal Dan Neonatal. Jakarta : YBP-SP. Tim karya tulis ilmiah. (2011). Panduan Karya Tulis Ilmiah. Akademik Keperawatan Kabupaten Cianjur.

Zietrelmart. (2015). http://zietraelmart. multiply.com, diperoleh tanggal 20 Maret 2015.

Zietrelmart. (2014). http://id.m.wiktionary. org/wiki/kepala_keluarga, diperoleh tanggal 24 februari 2015. 